\title{
Casein kinase II enhances the DNA binding activity of serum response factor
}

\author{
J. Robert Manak, Nathalie de Bisschop, Richard M. Kris, ${ }^{1,2}$ and Ron Prywes \\ Department of Biological Sciences, Columbia University, New York, New York 10027 USA; ${ }^{1}$ Rorer Biotechnology, Inc., King \\ of Prussia, Pennsylvania 19406 USA
}

Serum response factor (SRF) is a mammalian transcription factor that binds to the serum response element in the enhancer of the c-fos proto-oncogene and thus may mediate serum-induction of c-fos transcription. We report here that the DNA binding activity of recombinant SRF made in Escherichia coli can be greatly enhanced by incubation of the protein with HeLa cell nuclear extract. The enhancing activity is ATP or GTP dependent and cofractionates with a protein kinase that phosphorylates SRF on a specific tryptic peptide. Coincubation with phosphatase blocks the enhancing activity, further suggesting that the enhanced binding activity is due to phosphorylation. The specific tryptic phosphopeptide phosphorylated in vitro is also phosphorylated in vivo, demonstrating that this phosphorylation is physiologically important. We have localized the phosphorylation site by a small deletion mutant. Finally, we show that the kinase activity is provided by casein kinase II (CKII) or a close variant. The potential role of CKII as either a regulatory or constitutive modifier of SRF in vivo will be discussed.

[Key Words: DNA binding; serum response factor; phosphorylation; c-fos; CKII; transcription factor]

Received November 10, 1990; revised version accepted March 22, 1990.

It has become increasingly evident that phosphorylation of a variety of eukaryotic transcription factors plays a role in the expression of specific target genes (Sorger et al. 1987; Sorger and Pelham 1988; Yamamoto et al. 1988; Cherry et al. 1989; Gonzalez and Montminy 1989). Although a number of transcriptional regulators have been shown to be phosphoproteins, in only a few cases has phosphorylation been shown to directly affect transcriptional activation or DNA binding capabilities (Sorger and Pelham 1988; Yamamoto et al. 1988). Serum response factor (SRF), which binds to the $\mathrm{c}$-fos serum response element, is phosphorylated in vivo on serine residues, and phosphatase treatment has shown that phosphorylation is required for its DNA binding activity in vitro (Prywes et al. 1988a). It has been proposed that phosphorylation of transcription factors might provide an acidic blob for a transcriptional activator domain (Sorger and Pelham 1988) similar to those of GAL4 or GCN4 (for review, see Ptashne 1988) but it is less clear how protein phosphorylation might affect DNA binding.

Transcription of the c-fos proto-oncogene can be activated by treating cells with chemicals such as phorbol esters and calcium ionophores, growth factors such as epidermal growth factor and platelet derived growth factor, and serum (for review, see Curran 1988). The phorbol ester, growth factor, and serum responses are mediated by a sequence element, termed the serum re-

${ }^{2}$ Present address: Department of Pharmacology, New York University Medical Center, New York, New York 10016 USA. sponse element (SRE), located 300 bp $5^{\prime}$ to the transcription start site (Treisman 1985, 1986; Fisch et al. 1987; Greenberg et al. 1987; Gilman 1988). A specific 64-kD protein (SRF) that binds to the SRE was identified in nuclear extracts (Gilman et al. 1986; Prywes and Roeder 1986; Treisman 1986) and subsequently purified by DNA affinity chromatography (Treisman 1987; Prywes and Roeder 1987; Schroter et al. 1987). The gene encoding SRF has been cloned and in vitro-translated SRF derivatives were made to analyze the DNA binding activity (Norman et al. 1988). These studies showed that the protein binds DNA as a dimer and that the DNAbinding domain is located in the center of the protein (amino acids 133-264), whereas a dimerization domain was more specifically localized to amino acids $168-222$. The DNA-binding domain is unlike any of the known structural motifs for previously described DNA-binding proteins (i.e., zinc finger, helix-turn-helix, etc.). Additionally, it has been shown that SRF purified from HeLa cells and in vitro-translated SRF are both able to stimulate transcription in vitro, demonstrating that SRF is a positively acting transcription factor (Norman et al. 1988, Prywes et al. 1988b).

Serum induction of c-fos can occur in the presence of protein synthesis inhibitors, suggesting that post-translational events are involved in regulation of c-fos transcription (Greenberg et al. 1986). SRF's DNA binding activity in nuclear extracts was unchanged by serum treatment of HeLa and NIH-3T3 cells (Treisman 1986; Gilman et al. 1986; Prywes and Roeder 1986; Fisch et al. 
1987; Sheng et al. 1988/ but was increased by epidermal growth factor in A431 cells (Prywes and Roeder 1986). These results suggested that whereas the DNA binding activity of SRF is regulated in A431 cells, SRF's transcriptional activity must be the function regulated in HeLa and NIH-3T3 cells. Thus, regulation of both these activities must be addressed.

We studied further the structure, function, and regulation of SRF by synthesizing it in Escherichia coli. This paper describes a protein kinase in HeLa cells that dramatically increases the DNA binding activity of recombinant SRF in vitro. This kinase activity was subsequently found to be similar or identical to casein kinase II (CKII), a protein kinase whose activity is stimulated by growth factors (Sommercorn et al. 1987; Klarlund and Czech 1988; Ackerman and Osheroff 1989; Carroll and Marshak 1989).

\section{Results}

Synthesis of SRF in E. coli

A T7 bacterial expression system inducible with IPTG (Studier and Moffatt 1986) was used to express an SRF fusion protein in bacteria. A construct, pARSRF, was generated that contained a fusion of 11 amino acids of T7 phage gene 10 protein with amino acids $10-508$ of SRF derived from an SRF cDNA clone (Norman et al. 1988). Subsequently, the construct was modified to encode the authentic amino-terminal amino acids of SRF; however, identical results were obtained as those obtained with the fusion protein. Extracts of bacteria containing pARSRF or the control vector pAR3040, and either uninduced or induced with IPTG, were electrophoresed on an SDS-polyacrylamide gel. A prominent new protein was observable with the IPTG-induced pARSRFbacteria at an apparent molecular weight of $\sim 60 \mathrm{kD}$ (data not shown). To demonstrate more clearly that this band represents SRF, we analyzed the gel by immunoblotting using a rabbit sera directed against a synthetic peptide of the carboxyl terminus of SRF (see Methods). A $60-\mathrm{kD}$ reactive protein was strongly induced by IPTG in pARSRF-bacteria (Fig. 1A, lane 4). Because the antibody is directed against the carboxyl terminus, the reactivity demonstrates that the bacterial protein is full length.

To purify further bacterial SRF (BSRF), we excised and electroeluted the $60-\mathrm{kD}$ band from the gel. This was analyzed by immunoblotting and compared to SRF purified from HeLa cells (HSRF) (Prywes and Roeder 1987). BSRF migrated slightly faster in the gel than HSRF (Fig. 1A, lanes 5 and 6), suggesting that the difference may be due to post-translational modifications. Differences at the amino terminus are not responsible for the lower migration because SRF with the authentic amino terminus migrated at the same position as the fusion protein /data not shown).

The bacterial extracts were analyzed for DNA binding activity by gel mobility-shift assays. The extracts were denatured in guanidine hydrochloride and allowed to renature during dialysis. A specifically bound complex was observed when extracts from bacteria containing
pARSRF were incubated with an SRE oligonucleotide, whereas no binding was observed with the control pAR3040 extract (Fig. 1B, lanes 1 and 2). SRF in HeLa cell nuclear extracts migrated slightly, but reproducibly, slower than BSRF (lane 3). Antibodies to SRF caused BSRF to migrate more slowly in the gel mobility-shift assay, demonstrating further that the DNA binding is due to the bacterially synthesized SRF (Fig. 1C). The specificity of BSRF binding was compared to that of HSRF by DNase I footprint analysis. BSRF protected $\sim 20$ nucleotides spanning the c-fos SRE (see Prywes and Roeder 1987) in a manner indistinguishable from that of HSRF (Fig. 2). BSRF DNA binding could also be competed by a specific oligonucleotide in the gel mobilityshift assay as will be discussed below (Fig. 4D). We observed less of a difference between BSRF and HSRF binding activity in the DNase I protection gels than in gel mobility-shift assays (described below). This is probably because of the different conditions required to achieve binding and DNase protection. Electroeluted BSRF was also denatured, renatured, and found to have DNA binding activity (e.g., see Fig. 4, below) and this electroeluted protein was used in most of the subsequent experiments.

\section{Transcriptional activity of BSRF}

We analyzed BSRF for its ability to stimulate transcription in vitro. Template plasmids were used that contain the c-fos promoter from -53 to +42 , fused to the bacterial chloramphenicol acetyltransferase gene, with (pFC53X) or without (pFC53) one copy of an SRE oligonucleotide inserted at -53 (Prywes et al. 1988b). As an internal control, an adenovirus major late promoter plasmid (pMls), in which control regions upstream of -51 are deleted, was included. The transcription products were assayed by $S 1$ nuclease analysis using two probes specific for the fos and major late transcripts. In this assay, both BSRF and HSRF specifically increased transcription from pFC53X about fivefold (Fig. 3). To quantitatively compare the activities, we used the gel mobility-shift assay to normalize for SRF's DNA binding activity. Both BSRF and HSRF were first incubated with the transcription extracts to account for the possibility that the extracts may alter their DNA binding activity. On titration of BSRF and HSRF (containing equal DNA binding activities), we found that BSRF had similar or slightly higher transcription activity than HSRF (data not shown). To our surprise, however, the DNA binding activity of BSRF was much higher after incubation with the transcription extracts. This suggested to us that there may be an activity in the transcription extracts that increases BSRF's DNA binding activity.

\section{Enhanced DNA binding of BSRF}

In an effort to look for evidence of an enhancing activity in HeLa cells that may increase the affinity of BSRF for its DNA binding site, we incubated BSRF with both nuclear and cytoplasmic fractions either in the presence or 


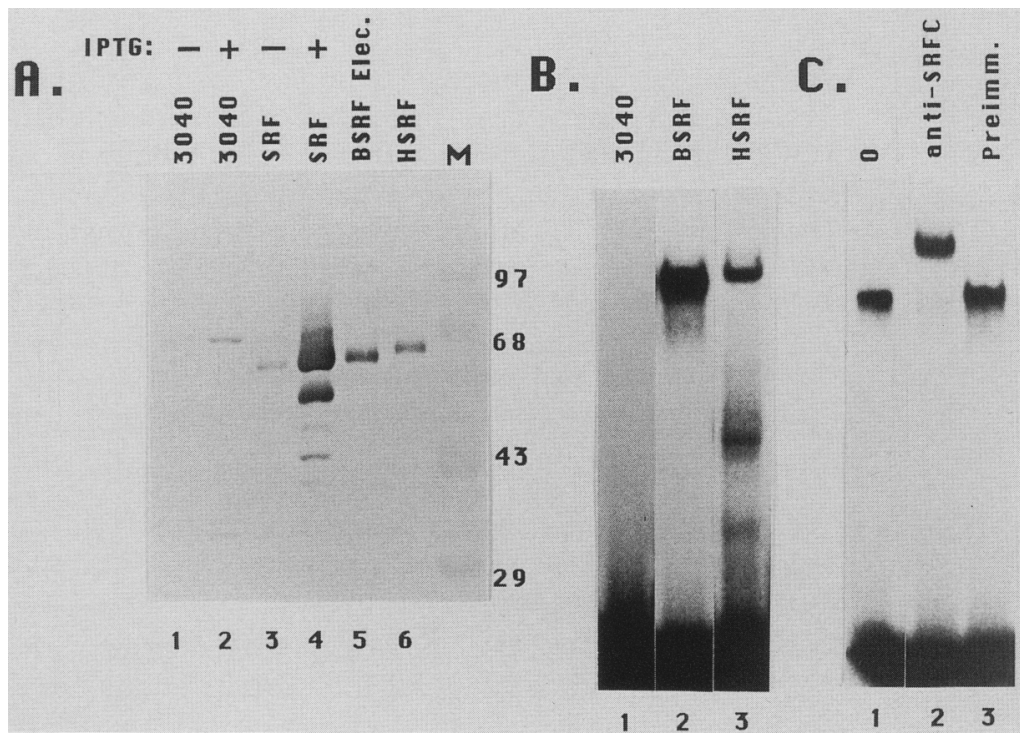

Figure 1. SRF produced in bacteria. $(A)$ Immunoblot of bacterial extracts. Extracts were prepared from bacteria containing either SRF expression plasmid pARSRF or the parental vector, pAR3040, and either uninduced $(-)$ or induced $(+)$ with IPTG as indicated. Bacterial extracts as well as electroeluted bacterial SRF (BSRF) and purified HeLa cell SRF (HSRF) were analyzed by immunoblotting using a rabbit antisera directed against a carboxyterminal synthetic peptide of SRF (anti-SRFC). The sizes of marker proteins, in kilodaltons, are indicated. $|B|$ DNA binding of bacterial SRF. The DNA binding activity of extracts $(1 \mu \mathrm{l})$ prepared from IPTG-induced bacteria containing pAR3040 (3040) or pARSRF (BSRF) was measured by gel mobilityshift assays with the high affinity SRE oligonucleotide, XGL, as the labeled DNA probe. SRF binding activity in HeLa cell nuclear extract (HSRF) $(1 \mu l)$ was measured in parallel. $(C)$ Protein specificity of DNA binding. The retarded DNA-protein complex was shown to contain SRF by further shifting the complex with anti-SRFC sera. Controls of no sera or preimmune rabbit sera were added as indicated.

absence of ATP. Interestingly, we found that the nuclear and cytoplasmic extracts dramatically increased the specific DNA binding of BSRF and that this stimulation was ATP dependent (Fig. 4A). The stimulation observed that was not ATP dependent (cf. lane 1 with lanes 3, 6, or 9) may be due to general protein stabilization of BSRF by the extracts. The level of HSRF endogenous to the extracts was low enough (lanes 4 and 10) not to obscure

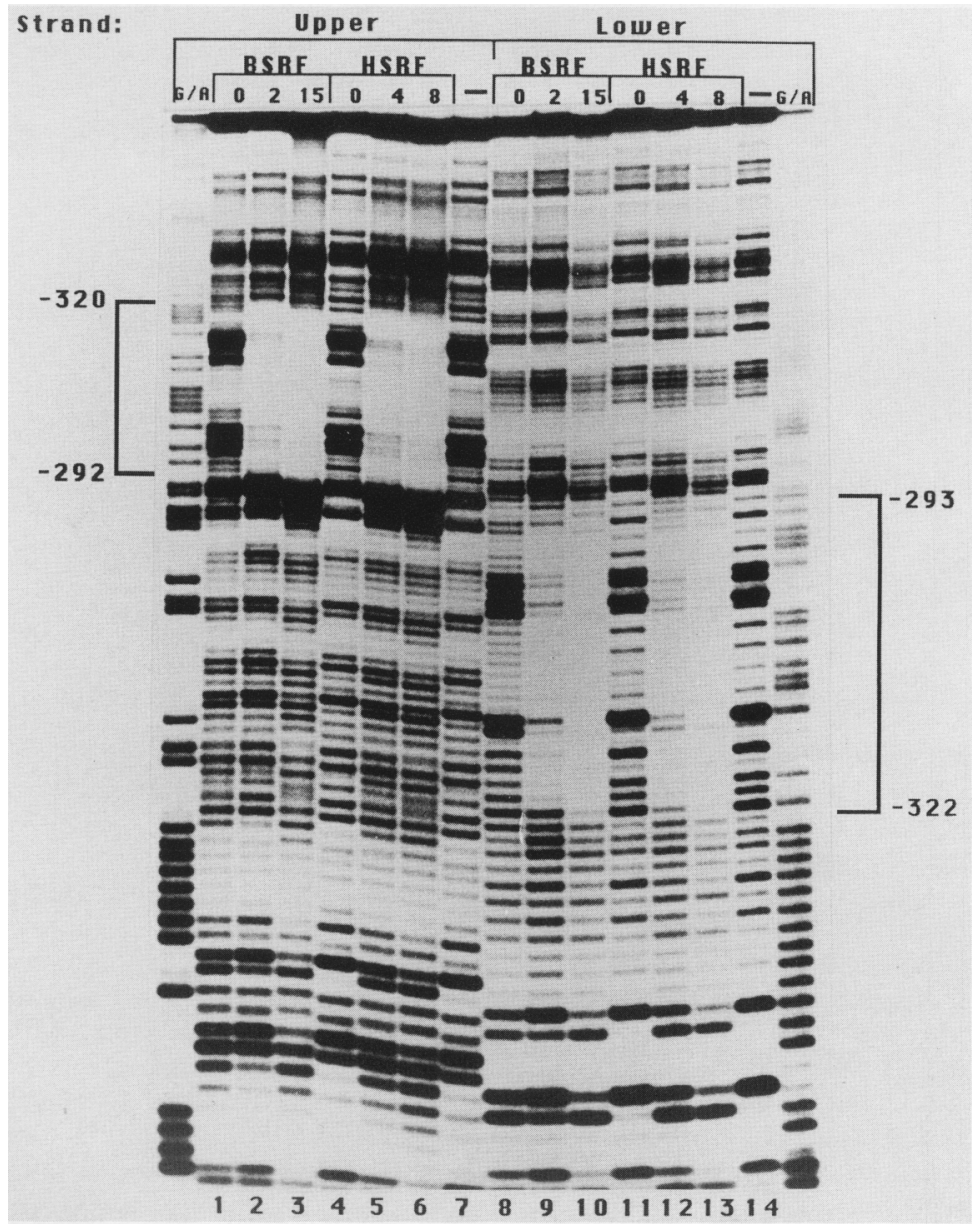

Figure 2. DNase I protection comparison of bacterial and HeLa cell SRF. The indicated amounts of either crude denatured/renatured bacterial pARSRF extract or HSRF (in microliters) were incubated with $2 \mathrm{ng}$ of ${ }^{32} \mathrm{P}$ labeled c-fos DNA in the presence of $200 \mathrm{ng}$ of herring sperm DNA and treated with DNase I. The DNA was isolated and analyzed on a sequencing gel. Control pAR3040 extract $(15 \mu \mathrm{l})$ was included in the BSRF lanes labeled 0 . Upper and lower strands as well as the position of the protected bases spanning the c-fos SRE are indicated relative to the c-fos transcriptional initiation site. The G/A-sequencing lanes of the c-fos fragment are indicated. SRF protein concentrations: $\sim 20 \mathrm{ng} / \mu \mathrm{l}$ for the crude BSRF, $\sim 5 \mathrm{ng} / \mu \mathrm{l}$ for purified HSRF. 


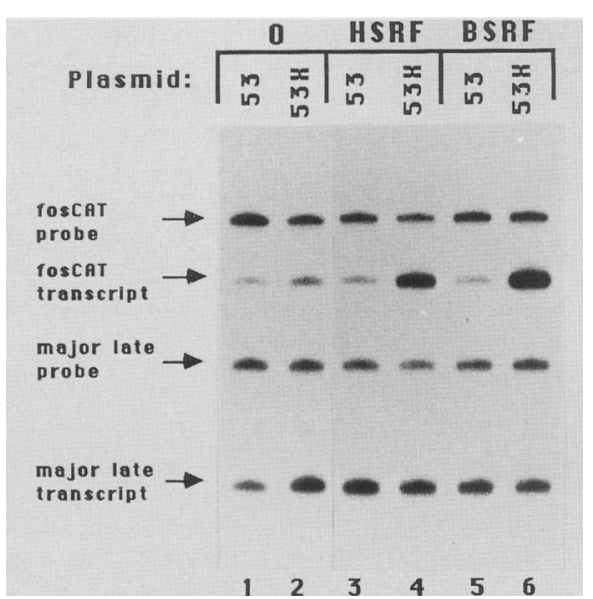

Figure 3. Transcriptional activity of BSRF in vitro. Either electroeluted BSRF $(0.1 \mu \mathrm{l}, \sim 2 \mathrm{ng})$ or purified HSRF $(0.1 \mu \mathrm{l}$, $\sim 0.5 \mathrm{ng}$ ) was added to in vitro transcription reactions and assayed by $\mathrm{S} 1$ nuclease analysis. FosCAT template plasmids, pFC53X or pFC53 (with or without SRF-binding oligonucleotide XGL inserted 53 nucleotides upstream of the transcriptional initiation site, respectivelyl, were used as indicated. Adenovirus major late promoter plasmid pMls (lacking upstream control regions beyond -51 ) was included as an internal control. The positions of the specifically initiated transcripts and reannealed probes are indicated. the activity of BSRF in the gel mobility-shift assay. To confirm that endogenous SRF did not interfere with the assay, we depleted HSRF in the nuclear extract by incubation with a specific oligonucleotide resin (Prywes et al. 1988a). Depleted nuclear extract gave similar results to normal nuclear extract (lanes 5-7). We observed that, upon phosphocellulose (P11) chromatography of HeLa cell nuclear extracts, the $0.5-$ to $0.85-\mathrm{M} \mathrm{KCl}$ step fraction was particularly enriched in the enhancing activity (Fig. 4B, lanes 1-3; and data not shown). We then tested whether affinity-purified HeLa cell SRF was stimulated in a similar fashion (Fig. 4B, lanes 4-6). Although addition of the P1l $0.85-\mathrm{M} \mathrm{KCl}$ fraction appeared to increase the binding capability of HSRF slightly, this effect was not ATP dependent. Similar to the stimulation of BSRF in the absence of ATP, we believe that the ATP-independent stimulation of HSRF is primarily a stabilization effect on the HSRF-DNA interaction.

The amount of BSRF used had an important effect on the level of increased binding seen. With high amounts of BSRF (20 ng) only a fewfold increase was seen, whereas with low amounts ( $1 \mathrm{ng}$ ) a $>20$-fold increase in DNA binding activity was observed (data not shown). Enhanced BSRF had similar DNA binding activity as SRF purified from HeLa cells when similar molar amounts were used (data not shown).

Because BSRF was electroeluted, denatured, and renatured, we sought to rule out that the enhanced binding was due to enhanced renaturation. We tested the ability of the enhancing activity to stimulate binding by HSRF
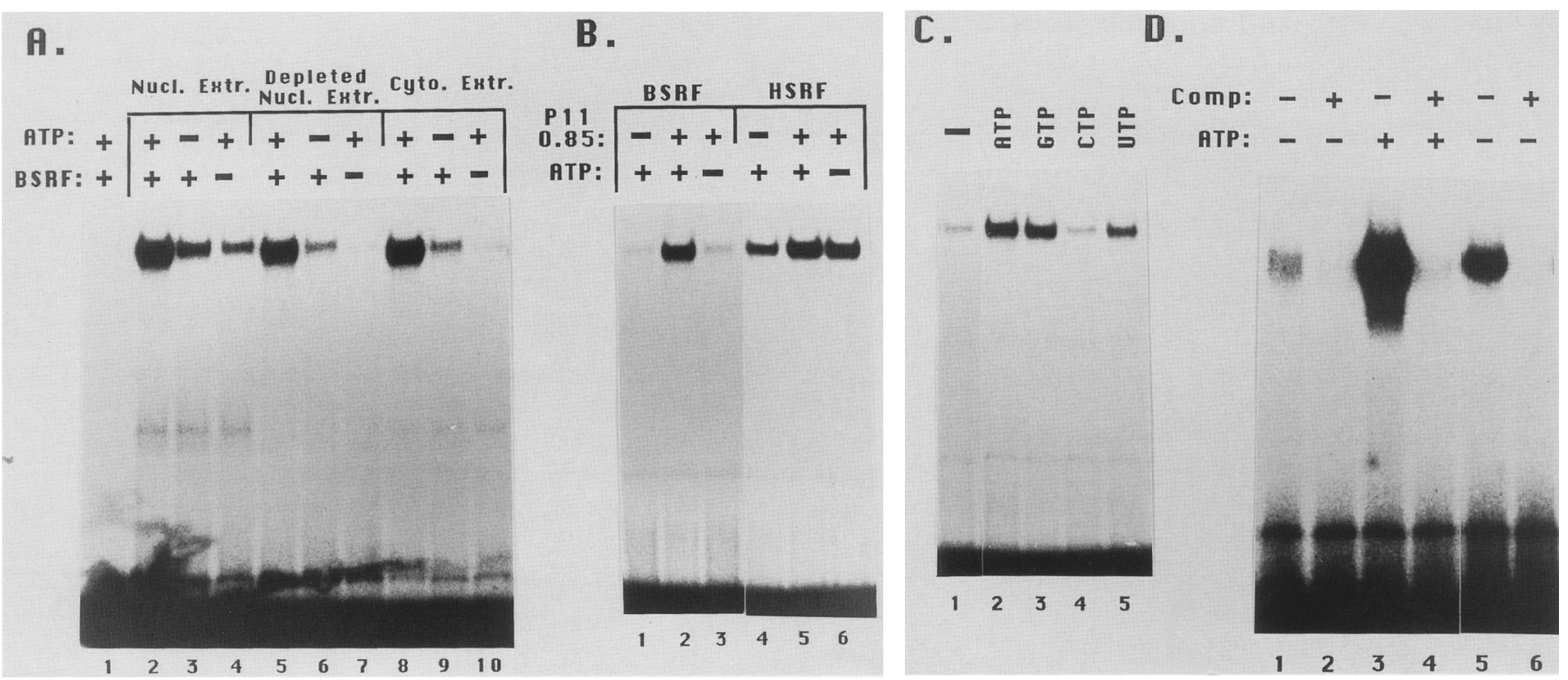

Figure 4. Enhanced DNA binding of BSRF. $(A)$ HeLa cell extracts enhance BSRF DNA binding. Binding activity of electroeluted BSRF $(0.1 \mu \mathrm{l})$ after incubation with nuclear or cytoplasmic extracts of HeLa cells $(1 \mu \mathrm{l}$ each), in the presence or absence of ATP, was measured in a gel mobility-shift assay. Where indicated, nuclear extract was depleted of endogenous SRF activity by incubation with a specific oligonucleotide resin. $(B)$ HeLa cell SRF DNA binding activity is not enhanced. Enhancing activity in HeLa cell nuclear extracts was fractionated on a phosphocellulose $(\mathrm{Pl} 1)$ column and the $0.5-$ to $0.85-\mathrm{M} \mathrm{KCl}$ step fraction $(0.5 \mu \mathrm{l})$ was incubated with either electroeluted BSRF $(0.3 \mu \mathrm{l})$ or SRF purified from HeLa cells $(0.3 \mu \mathrm{l})$, with or without ATP. $(C)$ Nucleotide requirement of the enhancing activity. BSRF's DNA binding activity was measured after incubation of BSRF $(0.1 \mu l)$ with the P11 0.85-M KCl fraction $(3 \mu l)$ in the presence or absence of the indicated nucleotidyl triphosphates. $(D)$ Specificity of BSRF binding. BSRF $(0.2 \mu)($ lanes $1-4)$ or HSRF $(0.1 \mu l)$ (lanes 5 and 6) was incubated with or without the P11 $0.85-\mathrm{M} \mathrm{KCl}$ fraction $(0.5 \mu l)$, and its DNA binding activity measured in the presence of either specific (XGL, +) or nonspecific (XGLM, - ) oligonucleotide competitors as indicated. 
that had been similarly electroeluted, denatured, and renatured (Prywes and Roeder 1987). As described above for native HSRF, we detected no ATP-dependent stimulation of DNA binding for the renatured HSRF (data not shown).

\section{Parameters of the enhancing reaction}

To determine whether we were observing an enzymatic activity, we performed experiments designed to determine the parameters of the enhancing phenomenon. First, we looked at nucleotide dependence of the enhancement activity (Fig. 4C). We observed maximal enhancement when the incubation was carried out in the presence of ATP or GTP. UTP gave less of a stimulatory effect, whereas CTP had no effect. On titration of the nucleotides, near maximal enhancement was obtained with $25 \mu \mathrm{M}$ ATP and GTP and with $100 \mu \mathrm{M}$ UTP (data not shown). The deoxynucleotidyl triphosphates worked as well as their nucleotidyl triphosphate counterparts, and neither ADP nor APPNP (a nonhydrolyzable analog of ATP) worked to enhance binding (data not shown).

We next determined the time and temperature dependence of the enhancing reaction. We found that the reaction worked best at $37^{\circ} \mathrm{C}$ and that maximal binding was achieved after $30 \mathrm{~min}$ of incubation. Preincubation of the P1l $0.85-\mathrm{M} \mathrm{KCl}$ fraction for $5 \mathrm{~min}$ at temperatures $>55^{\circ} \mathrm{C}$ abolished the enhancing activity. Moreover, incubation reactions carried out on ice also showed no enhancing activity (data not shown).

Finally, a metal ion was required as a cofactor in the reaction. $\mathrm{Mg}^{2+}$ gave near-maximal stimulation at a concentration of $300 \mu \mathrm{M}$, whereas $\mathrm{Mn}^{2+}$ and $\mathrm{Ca}^{2+}$ gave a significant stimulatory effect only at very high concentrations (above $10 \mathrm{mM}$ ). $\mathrm{Zn}^{2+}$ and $\mathrm{Cu}^{2+}$ were not stimulatory at any concentration (data not shown).

\section{Specificity of BSRF DNA binding}

The specificity of DNA binding by BSRF, before and after enhancement, was confirmed by competition with specific (XGL) or mutated (XGLM) oligonucleotides. In all cases, binding was specific and could be competed only by XGL (Fig. 4D).

In the experiments described above, we used ${ }^{32} \mathrm{P}$-labeled oligonucleotide XGL (Prywes et al. 1988b) as the gel mobility-shift probe. This DNA is similar to oligonucleotide ActL (Treisman 1987), is a perfect inverted repeat of the left half of an SRE in the Xenopus $\gamma$-actin gene, and binds SRF with 10 -fold greater affinity than the c-fos SRE (Treisman 1987; Prywes et al. 1988a). We also used the c-fos SRE and observed a similar increase in BSRF's binding activity to this sequence (data not shown).

\section{Phosphorylation of BSRF}

Because of the ATP dependence of the enhancing activity, we tested whether the $\mathrm{P} 110.85 \mathrm{M} \mathrm{KCl}$ fraction could phosphorylate BSRF. The reaction was performed with $\left[\gamma^{-32} \mathrm{P}\right] \mathrm{ATP}$, and BSRF was subsequently immunoprecipitated and analyzed on an SDS-polyacrylamide gel. BSRF was indeed phosphorylated by the P11 fraction, whereas no phosphorylation was observed with either BSRF or the P11 fraction alone (Fig. 5A). The immunoprecipitation of phosphorylated BSRF could be blocked by the antibodies' cognate peptide, demonstrating that BSRF rather than a contaminating bacterial protein was in fact precipitated (data not shown).

We showed previously that SRF is phosphorylated in vivo in HeLa and A431 cells by labeling cells with ${ }^{32} \mathrm{P}$ inorganic phosphate and purifying SRF with a specific oligonucleotide resin (Prywes et al. 1988b). We repeated this experiment except we used the anticarboxy-terminal peptide sera to immunoprecipitate SRF instead of using the oligonucleotide resin. Again we found that SRF is phosphorylated in vivo and that the specificity of immunoprecipitation can be demonstrated by competition with the cognate peptide (Fig. 5B).

To confirm further that the enhancing activity was due to phosphorylation of BSRF, we conducted the enhancing reaction in the presence or absence of potato acid phosphatase (PAP) and measured BSRF's DNA binding activity. PAP was able to block the enhancement of DNA binding activity (Fig. 5C, cf. lanes 2 and 6), and this effect was blocked by $12 \mathrm{~mm}$ sodium phosphate used as a phosphatase inhibitor (lane 5). The unstimulated BSRF DNA binding activity was faint but was clearly not affected by PAP treatment (lanes 1, 3, and 4; data not shown).

\section{Partial purification of the enhancing activity}

We sought to partially purify the enhancing activity by chromatography to determine whether there is a discrete activity involved and whether the kinase activity described above copurifies with the enhancing activity. We first fractionated HeLa cell nuclear extract on a phosphocellulose (P11) column and eluted with a gradient of 0.1 to $1.0 \mathrm{M} \mathrm{KCl}$. The fractions were subsequently analyzed for DNA binding enhancement and kinase activities (Fig. 6A,B). The enhancing activity fractionates as a single peak, eluting between 550 and $800 \mathrm{~mm} \mathrm{KCl} \mathrm{(Fig.}$ 6A). The kinase activity similarly eluted as a single peak in the same position (Fig. 6B). Kinase activity was also apparent in lower fractions than is observed for the enhancing activity, but we believe this to be due to the greater sensitivity of the kinase assay. With the kinase activity eluting at relatively high salt, we obtained about a 20 -fold purification on the P1l column.

To purify further the enhancing activity, we used a 0.5- to $0.85-\mathrm{M} \mathrm{KCl}$ step eluate of a P11 column. This step fraction was applied to an FPLC Mono Q column and eluted with a gradient of 0.1 to $0.5 \mathrm{M} \mathrm{KCl}$. The fractions were analyzed for kinase activity and DNA binding enhancement as described above. Again, both the DNA binding enhancement and kinase activities eluted as discrete overlapping peaks at about $400 \mathrm{~mm} \mathrm{KCl}$ (Fig. $6 \mathrm{C}, \mathrm{D})$. This column gave a 5- to 10 -fold purification such that the activities were copurified at least 100 -fold 
Figure 5. Phosphorylation of SRF. $(A)$ In vitro labeling of BSRF. Electroeluted BSRF $(0.5 \mu 1)$, the $\mathrm{P} 110.85-\mathrm{M} \mathrm{KCl}$ fraction $(0.6 \mu l)$, or both together were incubated with $\left[\gamma^{-32} \mathrm{P}\right] \mathrm{ATP}$, immunoprecipitated with anti-SRFC and analyzed on an $8 \%$ SDS-polyacrylamide gel. $(B)$ In vivo labeling of SRF. A431 cells were labeled in vivo with ${ }^{32} \mathrm{p}$-inorganic phosphate for $3 \mathrm{hr}$ and SRF was immunoprecipitated with anti-SRFC. To demonstrate the specificity of precipitation, either the antibody's cognate peptide $C$ or a nonspecific peptide $\mathrm{M}$ were included as indicated. $(C)$ Phosphatase sensitivity of DNA binding enhancement. BSRF $(0.13 \mu \mathrm{l})$ was incubated with or without the $\mathrm{P} 110.85-\mathrm{M} \mathrm{KCl}$ fraction $(3 \mu \mathrm{l})$, potato acid phosphatase $(1.5 \mu \mathrm{g})$, or both in the presence or absence of $12 \mathrm{~mm}$ sodium phosphate as a phosphatase inhibitor.

through the two columns. Fraction number 23 was used as the Mono Q kinase fraction for the experiments described below.

\section{Site of phosphorylation is discrete and present in vivo}

To characterize the site of phosphorylation, we excised in vitro-phosphorylated BSRF from an SDS-polyacrylamide gel (as in Fig. 5A) and treated it with trypsin. The phosphotryptic peptides were then analyzed by HPLC reverse-phase chromatography. Only one unique peptide was phosphorylated in vitro on BSRF (Fig. 7, top). Because we failed to detect phosphorylation of BSRF in bacteria by metabolic labeling (data not shown), it appears that this unique peptide represents the only phosphorylated region of the protein.

To substantiate the in vivo relevance of the site of phosphorylation, we also performed phosphotryptic peptide analysis on SRF immunoprecipitated from A431 cells labeled in vivo with ${ }^{32} \mathrm{P}$-inorganic phosphate las in Fig. 5B). Two predominant phosphopeptides were observed, one of which precisely coeluted at the position of the BSRF phosphopeptide (Fig. 7, bottom). A shoulder is apparent on the second peak (fraction 34) and may represent a third site of phosphorylation in vivo. We found previously that SRF was labeled on as many as seven tryptic peptides (Prywes et al. 1988a). We believe that this greater number of labeled peptides was due to partial tryptic digestion.

We also found previously that SRF was labeled on serine residues in vivo (Prywes et al. 1988a). We tested the site of in vitro phosphorylation of BSRF by phosphoamino acid analysis of the tryptic phosphopeptide and found phosphorylation exclusively on serine (data not shown).

The specificity of SRF phosphorylation causing enhanced DNA binding was further highlighted by the observation that purified cAMP-dependent protein kinase (Sigma) had no effect on SRF's DNA binding activity in vitro (data not shown).

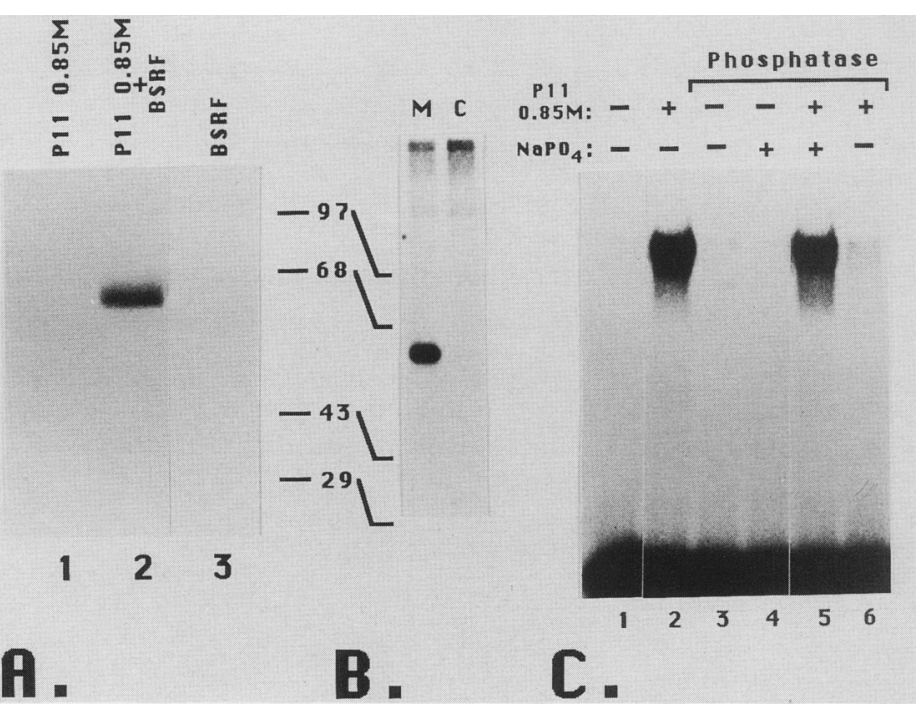

The kinase activity is similar to CKII

Several properties of our kinase activity were reminiscent of CKII: utilization of GTP as well as ATP, cellular localization to both nuclear and cytoplasmic fractions, and elution at high salt in phosphocellulose chromatography (Hathaway et al. 1979; Hathaway and Traugh 1979; Edelman et al. 1987). We therefore tested for the ability of CKII to phosphorylate BSRF and enhance its DNA binding activity. CKII purified from bovine testes (Takio et al. 1987) did in fact catalyze both reactions (Fig. 8).

Further, we found that our Mono Q kinase fraction also phosphorylated casein (Fig. 9B). Titration of this fraction and CKII showed that they had similar relative activities in three assays: phosphorylation of casein, phosphorylation of SRF, and stimulation of SRF DNA binding (data not shown).

Another hallmark of CKII is its inhibition by low concentrations of heparin (Hathaway et al. 1980). We found that both the Mono Q fraction and CKII were inhibited at identical concentrations of heparin (Fig. 9). Interestingly, $4 \mu \mathrm{g} / \mathrm{ml}$ heparin was required to completely inhibit phosphorylation of SRF by both kinase fractions whereas $<0.4 \mu \mathrm{g} / \mathrm{ml}$ heparin was required to inhibit their ability to phosphorylate casein (Fig. 9, cf. A and B).

CKII phosphorylates serine residues on the amino-terminal side of a string of 4-5 acidic residues (Krebs et al. 1988). Such a site exists at amino acid 85 of SRF (SerGly-Glu-Glu-Glu-Glu). To test for phosphorylation at this site, we deleted amino acids $70-92$ using a convenient Narl restriction site. This mutant, SRF $\Delta 70-92$, was made abundantly in bacteria as assayed by Coomassie Blue staining of extracts electrophoresed on SDS-polyacrylamide gels as well as by immunoblots (data not shown). The deleted protein had low DNA binding activity that could not be enhanced by either our Mono Q fraction or CKII (Fig. 8A). The low binding activity of the mutant is more evident on longer exposures of the gel, where signals are clearly observed in the 


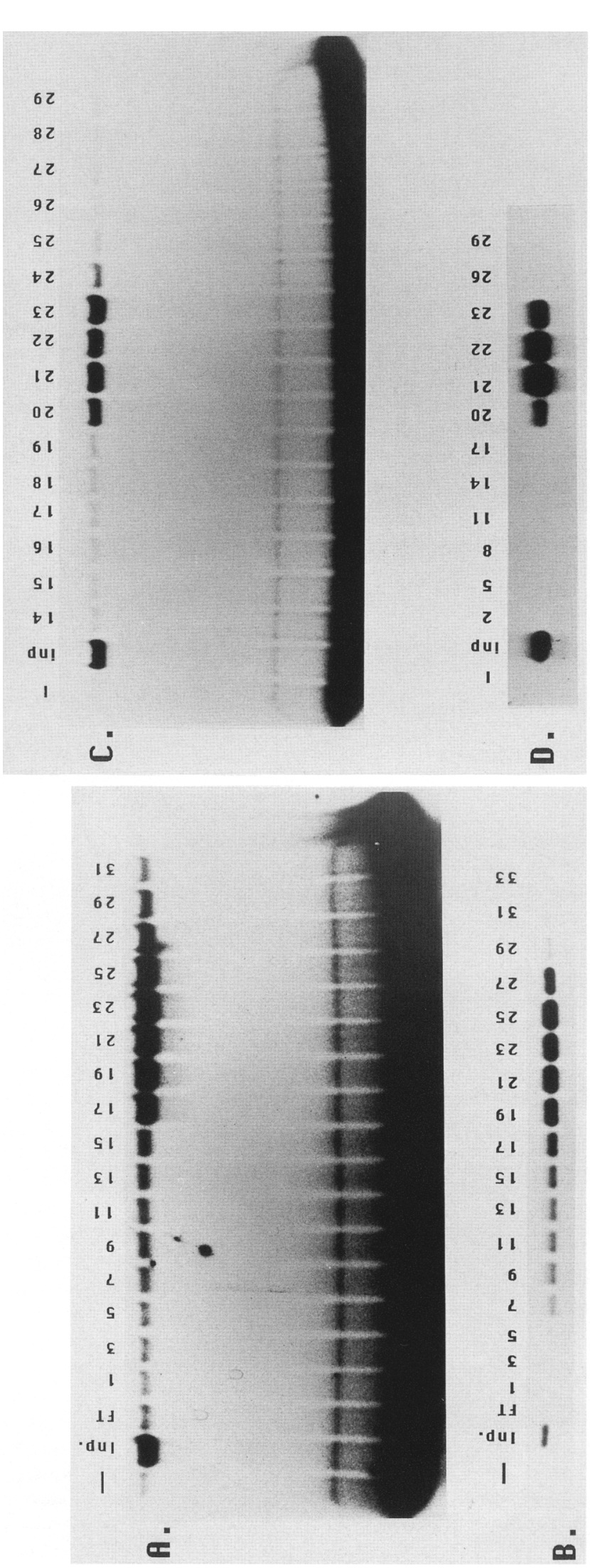

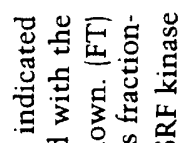

可

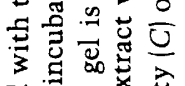

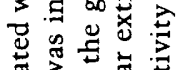

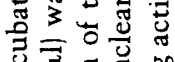

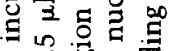

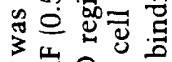

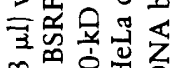

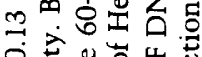

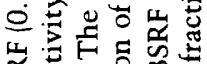

岩甜员

थ

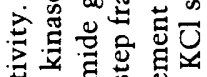

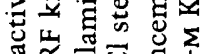

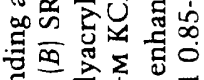

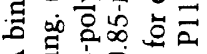

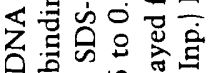

运 in

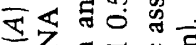

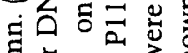

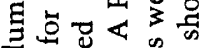

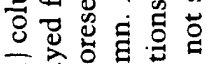

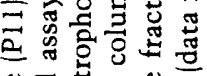

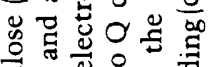

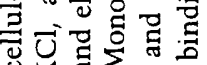

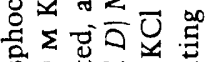

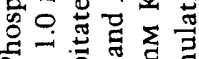

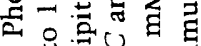

क

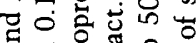

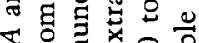

뎡

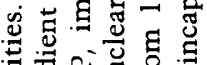

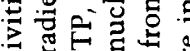

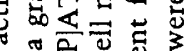

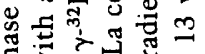

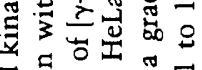

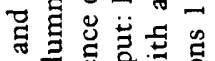

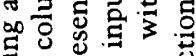

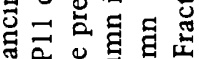

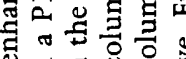

동ㅇㅇㅇ

연

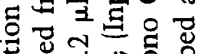

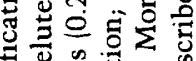

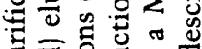

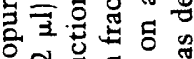

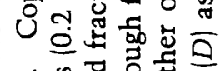

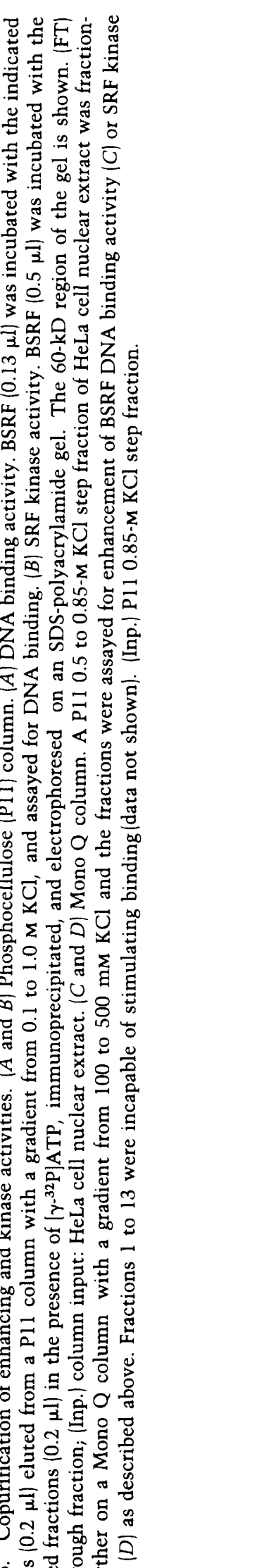

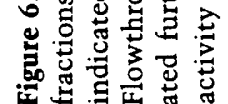




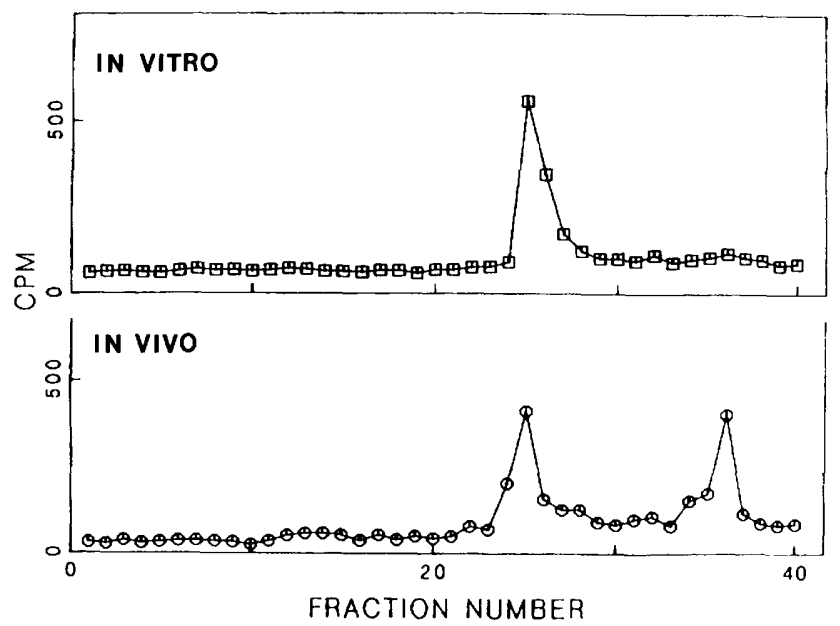

Figure 7. Phosphotryptic peptide analysis. (Top) BSRF phosphorylated in vitro with $\left[\gamma^{-32} \mathrm{P}\right]$ ATP was isolated, treated with trypsin, and analyzed on an HPLC reverse-phase column as described in Methods. (Bottom) In vivo phosphorylated SRF was immunoprecipitated from ${ }^{32} \mathrm{P}$-inorganic phosphate-labeled A431 cells and analyzed for phosphotryptic peptides as above.

lanes containing the mutant protein. Furthermore, SRF $\Delta 70-92$ was not phosphorylated effectively by either kinase preparation (Fig. 8B). A low level of phosphorylation of SRF $\Delta 70-92$, perhaps nonspecific, could be observed on longer exposure of the gel. Further supporting these results, a mutant with amino acids $1-141$ deleted behaved identically to SRF $470-92$, whereas a mutant with amino acids 339-508 deleted behaved identically to the wild-type protein (i.e., it was phosphorylated, and its DNA binding activity was stimulated by the Mono $Q$ fraction; data not shown).

\section{Discussion}

We found previously that SRF is phosphorylated in vivo and that phosphatase treatment reduces SRF's DNA binding activity in vitro (Prywes et al. 1988a). In this paper, we have gone on to identify a distinct protein $\mathrm{ki}$ nase in HeLa cells that phosphorylates bacterial SRF on a single tryptic peptide. This phosphorylation dramatically increases BSRF's DNA binding activity. The kinase we have identified appears to be identical to CKII.

Four criteria strongly suggest that the activity that enhances SRF's DNA binding is in fact a protein kinase. First, the enhancement of BSRF DNA binding activity is ATP or GTP dependent and cannot use ADP or a nonhydrolyzable ATP analog. Second, a protein kinase activity that can label BSRF with $\left[\gamma^{-32} \mathrm{P}\right]$ ATP copurifies lover 100-fold) with the enhancing activity through two columns. Third, coincubation with phosphatase strongly inhibits the enhancing activity and this inhibition can be blocked with the phosphatase inhibitor, sodium phosphate. Finally, highly purified CKII can also both phosphorylate and enhance the DNA binding activity of BSRF.

\section{Phosphorylation of SRF}

The site of BSRF phosphorylation in vitro was localized to a serine residue on a single tryptic peptide. This site was localized further by a mutant in which 23 amino acids were deleted, encompassing a consensus CKII site at amino acid 85. BSRF was efficiently phosphorylated at low concentrations (less than $1 \mathrm{nM}$ BSRF). The kinase activity must also be present at low concentrations in our crude extract preparations /where it has not been concentrated by purification). We contrast these results to the potentially artifactual method of using large amounts of purified protein kinases where low affinity substrates can be phosphorylated. The specificity and relevance of BSRF phosphorylation is additionally emphasized by the observation that the identical tryptic peptide (and presumably site) phosphorylated in vitro is also phosphorylated in vivo in A431 cells. Once phosphorylated, BSRF had similar DNA binding and in vitro

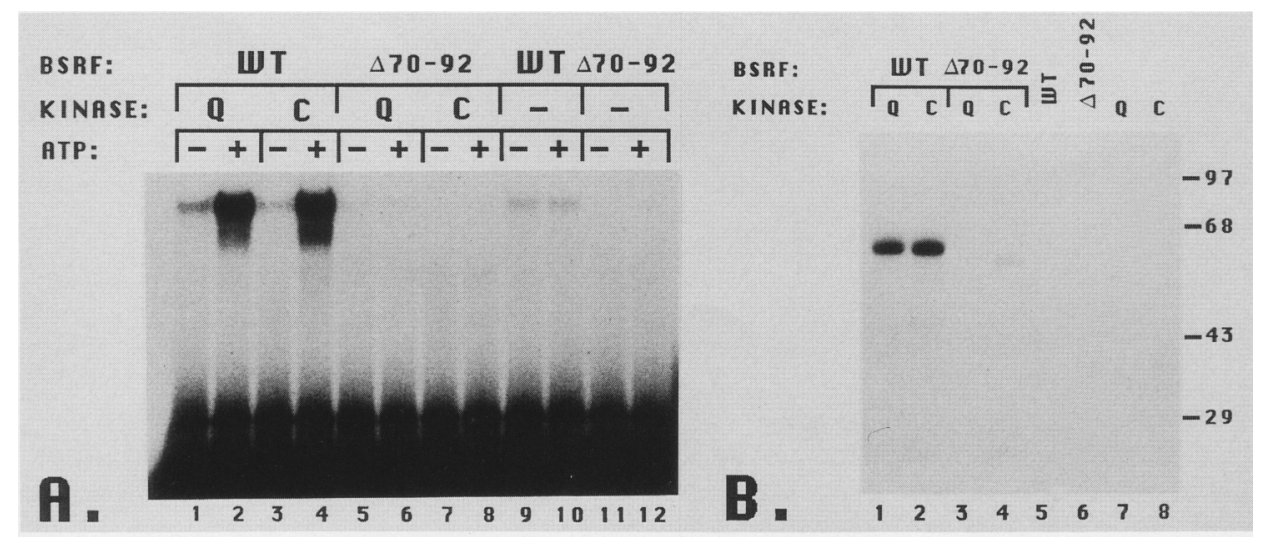

Figure 8. CKII phosphorylation of SRF. $(A)$ DNA binding activity of BSRF proteins incubated with kinase preparations. Bacterially made full-length SRF (WT; $0.25 \mu \mathrm{l}, 4 \mathrm{ng} / \mu \mathrm{l})$ or an SRF deletion mutant $(\Delta 70-92 ; 0.06 \mu \mathrm{l}, \sim 16 \mathrm{ng} / \mu \mathrm{l})$ were incubated with either the Mono $Q$ kinase fraction $(\mathrm{Q}, 2 \mu \mathrm{l})$ or CKII $(\mathrm{C}, 0.02 \mu \mathrm{l})$ in the presence or absence of ATP and were assayed for DNA binding activity using the gel mobility-shift assay. $(B)$ Phosphorylation of bacterially made mutant and full-length proteins. Approximately 12 ng of the indicated BSRF proteins was incubated with either the Mono Q kinase fraction $(2 \mu))$ or CKII $(0.02 \mu l)$ in the presence of $\left[\gamma^{-32} \mathrm{P}\right] \mathrm{ATP}$ and electrophoresed on a $9 \%$ SDS-polyacrylamide gel. The sizes of marker proteins, in kilodaltons, are indicated. 


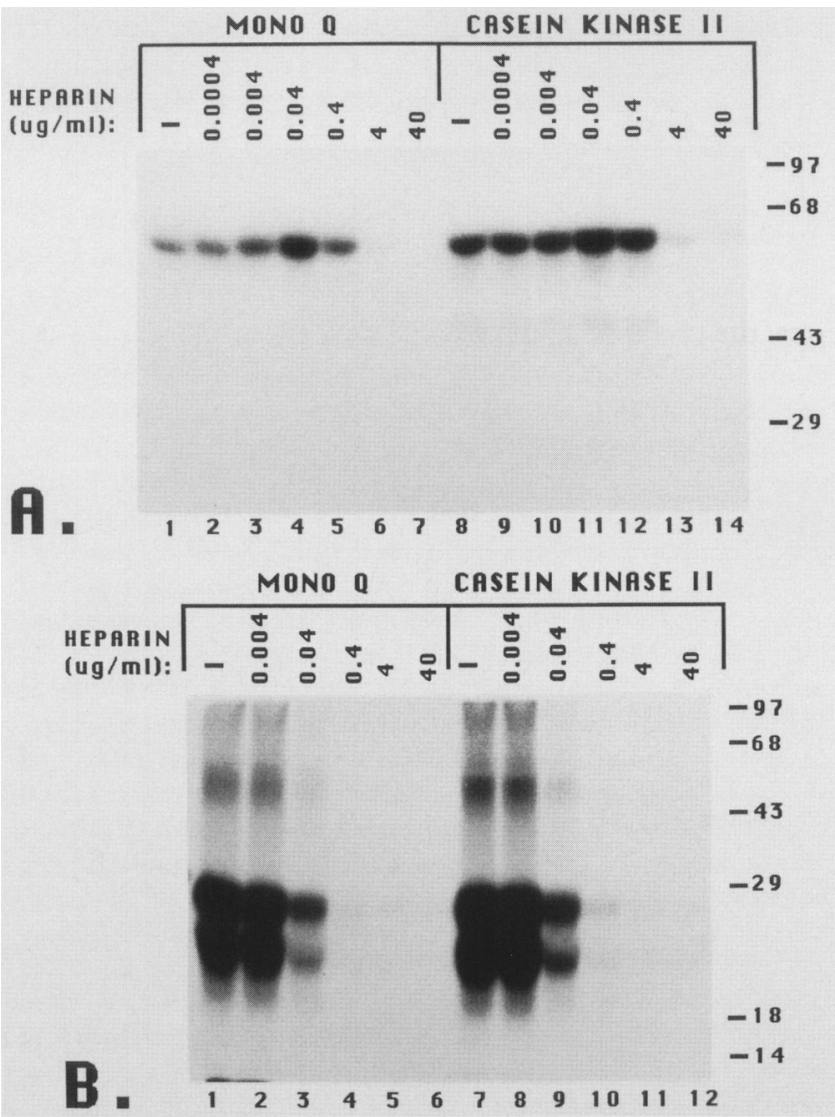

Figure 9. Heparin inhibition of kinase activity. $(A)$ Inhibition of BSRF phosphorylation. Approximately $24 \mathrm{ng}$ of full-length BSRF was treated with either the Mono Q kinase fraction $(2.5$ $\mu l)$ or CKII $(0.03 \mu l)$ in the presence or absence $(-)$ of various concentrations of heparin (as indicated) and electrophoresed on a $9 \%$ SDS-polyacrylamide gel. (B) Inhibition of casein phosphorylation. Casein $(0.6 \mu \mathrm{l}$ of a $5 \%$ solution) was incubated with either the Mono Q kinase fraction $(3 \mu))$ or CKII $(0.02 \mu l)$ in the presence or absence $(-)$ of various concentrations of heparin and electrophoresed on a $12 \%$ SDS-polyacrylamide gel. The sizes of marker proteins, in kilodaltons, are indicated.

transcription activity as SRF purified from HeLa cells (HSRF). We could not detect phosphorylation of BSRF in bacteria; this suggests that phosphorylation on a single tryptic peptide is sufficient to fully activate the DNA binding potential of SRF.

BSRF migrated faster on SDS-polyacrylamide gels than HSRF. Although phosphorylation by the kinase activity slowed the migration of BSRF, it still ran faster in the gels than HSRF (data not shown). The difference in mobility could be accounted for by a second phosphorylation of HSRF, as suggested by the phosphotryptic peptide analysis of in vivo-labeled SRF, or by other modifications, such as the glycosylation found with transcription factor SP1 (Jackson and Tiian 1988).

\section{CKII phosphorylates SRF}

The SRF kinase activity we have described in HeLa cell extracts appears to be identical to CKII. Purified CKII phosphorylated BSRF and stimulated its DNA binding activity to a similar extent as our kinase preparation. Furthermore, both kinase preparations had the same relative ability to phosphorylate SRF and casein, such that two kinases with differing affinities for these two substrates could not be distinguished. In addition, both kinase preparations were inhibited by low concentrations of heparin, a property unique to CKII (Edelman et al. 1987). Curiously, with both kinase preparations, the SRF phosphorylation was less sensitive to heparin than was casein phosphorylation, suggesting that two distinct kinases could be present in both preparations. Thus we cannot rule out the possibility that the SRF kinase we have identified is similar but not identical to CKII, as has been reported for an LDL receptor kinase (Kishimoto et al. 1987). Reagents specific to CKII will be required to definitively answer this question.

CKII phosphorylates serine residues amino terminal to a stretch of four to five acidic amino acids (Krebs et al. 1988). Thus the site of phosphorylation on SRF is most probably serine 85 where the sequence is Ser-Gly-GluGlu-Glu-Glu (Norman et al. 1988). In agreement with this, a small deletion mutant of amino acids 70-92 of SRF was not phosphorylated and its DNA binding activity could not be stimulated by either CKII or the SRF kinase from HeLa cells. Larger deletion mutants were also consistent with this result. Further biochemical characterization and missense mutants will be required to confirm the exact site of phosphorylation. The involvement of CKII in phosphorylation of SRF is particularly interesting because of reports that CKII activity is stimulated rapidly in cells by serum and growth factor treatment (Sommercorn et al. 1987; Klarlund and Czech 1988; Ackerman and Osheroff 1989; Carroll and Marshak 1989|. This would suggest a model where CKII is directly upstream of SRF in the signal transduction pathway that leads to $\mathrm{c}$-fos transcriptional activation in response to growth factors. The reported stimulation of CKII, however, varies from 1.3- to 6-fold. This variability may indicate that CKII or its substrates are very sensitive to experimental conditions.

We observed previously that the DNA binding activity of SRF was increased by treatment of A431 cells with epidermal growth factor (EGF) (Prywes and Roeder 1986). We have repeated this more definitively using the SRE oligonucleotide XGL in gel mobility-shift assays and obtained the same result (unpubl.). Because a potential mechanism for this increase could be phosphorylation by CKII, we analyzed A431 cells for changes in SRF phosphorylation after EGF treatment. Our preliminary results indicate, however, that there is no change in phosphorylation in vivo at either of the sites ( $N$. de Bisschop, R.M. Kris, and R. Prywes, unpubl.). Furthermore, we have not detected a change in SRF kinase activity in nuclear extracts from EGF-treated A431 cells (R. Prywes, unpubl.). These results suggest that CKII phosphorylation of SRF is a constitutive structural modification rather than regulatory in response to growth factors. Nevertheless, the phosphorylation of SRF certainly has the potential to be regulatory in A431 or other cell 
systems. Just as great variability has been observed for CKII stimulation by serum and growth factors, analysis of SRF phosphorylation may also be very sensitive to experimental conditions. We are currently trying to exclude various artifacts and test other cell types.

\section{Effect of phosphorylation on DNA binding}

Activation of a transcription factor's DNA binding activity by phosphorylation is quite unique, and it is unclear how phosphorylation might elevate BSRF's DNA binding activity. The DNase I protection pattern of BSRF before activation was indistinguishable from that of HSRF, suggesting that activation does not alter the way the protein contacts DNA. SRF dimerization is required for its DNA binding activity (Norman et al. 1988); therefore, regulation of dimerization could be the mechanism for regulation of DNA binding activity. Our preliminary results, however, argue against this because phosphorylation of BSRF did not affect its migration on native gels (R. Prywes, unpubl.). An alternative mechanism is that phosphorylation causes a conformational change in the protein to increase its affinity for DNA. It is possible that unphosphorylated SRF adopts the correct conformation inefficiently, and this accounts for the low level of binding observed. The putative CKII site at amino acid 85 is sufficiently far from the beginning of the DNA-binding domain (amino acid 133; Norman et al. 1988/ that without further structural studies, it is difficult to propose how phosphorylation might exert its effect.

A similar observation of enhanced DNA binding has been observed with the CREB transcription factor (which binds to cyclic AMP response elements). Purified protein kinase $C$ elevated CREB's DNA binding activity in vitro (Yamamoto et al. 1988) although it is still unknown whether CREB is modified by protein kinase $C$ in vivo. In the CREB case it was proposed that phosphorylation affects dimer formation and that dimers bind more efficiently to DNA. In contrast, the transcriptional activity of CREB, but not its DNA binding activity, was increased in vitro by phosphorylation with protein kinase A (Yamamoto et al. 1988). Along the same lines, the transcriptional activator function of the yeast heat shock factor correlates with phosphorylation since at high temperature the factor becomes multiply phosphorylated. This phosphorylation had no effect on its DNA binding activity (Sorger and Pelham 1988). Recently, SV40 T antigen was shown to be phosphorylated in vitro on threonine 124 by the cdc 2 protein kinase. This phosphorylation increased T-antigen DNA binding activity to the SV40 origin and elevated its replication activity dramatically (McVey et al. 1989). The effects of phosphorylation on the transcriptional properties of SV40 T antigen are not known. These examples demonstrate that the effect of phosphorylation can be divided into two classes: one affecting DNA binding activity and the second affecting the transcriptional activator function.

The requirement of phosphorylation for DNA binding activity may become more general as more factors are analyzed. It will be interesting in inducible transcription systems to see whether phosphorylation is regulatory and to see which protein kinases are involved.

\section{Methods}

Plasmid constructions

Initially, an SRF fusion protein construct was made using the plasmids pAR3040, a T7 polymerase expression vector (Studier and Moffatt 1986), and pT7 $\triangle A T G$ (Norman et al. 1988), which encodes the complete SRF protein and which was kindly provided by $R$. Treisman. Plasmid pT7 $\triangle$ ATG was digested with $B g I I$, treated with $\mathrm{T} 4$ polymerase to creat blunt ends, ligated to a BamHI linker, and digested with BamHI. A 1.6-kb fragment was purified and ligated into pAR3040 digested with BamHI and treated with calf intestinal alkaline phosphatase (Boehringer-Mannheim). This clone, pARSRF, was transformed into bacteria (strain BL21; Studier and Moffatt 1986) and the bacteria were induced with IPTG (isopropyl- $\beta$ - $D$-thiogalactopyranoside) to produce a fusion protein that contained the first 11 amino acids of the gene 10 protein (a major capsid protein of T7) as well as 3 amino acids from the BamHI linker and in which the first 9 amino acids of SRF are replaced. To construct a clone capable of producing full-length SRF protein, two phosphorylated oligos (CATATGTTACCGACCCCAGCTGGGGCCGCGGCGGC and GCCGCCGCGGCCCCAGCTTGGGTCGGTAACATATG) were annealed and used in a three-part ligation with a $1.6-\mathrm{kb} B g h-B a m H I$ fragment of pT7 $\triangle$ ATG as well as an NdeI-BamHI fragment of pAR3040. This produced a construct (pARSRF-Nde) that contained an NdeI site at the initiation codon of SRF.

To construct the amino-terminal deletion that removed amino acids $1-141$, pARSRF-Nde was first digested with SmaI. A BamHI 8-mer linker (New England Biolabs) was cloned into the SmaI site, the clone was digested with BamHI, and a $1.2-\mathrm{kb}$ fragment was purified and subsequently subcloned into the pAR3040 fragment that was purified from the same gel. The deletion of amino acids 339-508 was generated by the removal of a PvuII-BamHI fragment of pARSRF-Nde and the reclosing of the plasmid with an XbaI termination linker (New England Biolabs) inserted between the ends. The deletion of amino acids $70-92$ was generated by partial cleavage with NarI, the insertion of a SacI 8-mer linker, and the reclosing of the plasmid.

\section{Preparation of bacterial protein extracts}

Preparation of bacterial protein extracts was essentially as described in Hoey et al. (1988) except that extract pellets were resuspended in $\mathrm{BC} 100[20 \%$ glycerol, $100 \mathrm{mM} \mathrm{KCl}, 0.2 \mathrm{~mm}$ EDTA, $20 \mathrm{~mm}$ Tris-HCl (pH 7.9), 0.05\% Nonidet P-40 (NP40), $0.5 \mathrm{mM}$ dithiothreitol (DTT), and $0.5 \mathrm{~mm}$ phenylmethylsulfonyl fluoride (PMSF) containing $6 \mathrm{M}$ guanidine hydrochloride (Gd-HCl), mixed for $20 \mathrm{~min}$ at room temperature, and dialyzed overnight against $\mathrm{BCl} 100$ at $4^{\circ} \mathrm{C}$. Insoluble material was removed by centrifugation for $5-10 \mathrm{~min}$ at $13,000 \mathrm{~g}$ and the resulting supernatant (typically containing $\sim 5 \mathrm{ng} / \mu \mathrm{l} \mathrm{BSRF}$ ) was used in our various assays.

Electroeluted bacterial SRF was prepared by the electrophoresing of IPTG-induced, pARSRF-bacterial extract pellets on $9 \%$ SDS-polyacrylamide gels (Laemmli 1970) in Tris-glycine running buffer ( $25 \mathrm{mM}$ Tris, $192 \mathrm{~mm}$ glycine, $0.1 \%$ SDS). The gels were stained and destained with $200 \mathrm{mM} \mathrm{KCl}$ and water, respectively, to visualize the protein bands. The appropriate bands were excised, electroeluted into Tris-glycine running buffer 
with $0.05 \%$ SDS at 200 volts for $30 \mathrm{~min}$, the eluate was lyophilized, and the protein was denatured and renatured with $\mathrm{BC100/6} \mathrm{M} \mathrm{Gd-HCl}$ and $\mathrm{BClO0}$, respectively, as described above.

Immunoblotting was as described (Prywes et al. 1988a) except that a 1:500 dilution of anti-SRFC (see below) was incubated with the nitrocellulose filter for $4 \mathrm{hr}$ at room temperature.

\section{DNase I protection}

DNase I protection assays were performed as described in Hoey et al. (1988) except that $200 \mathrm{ng}$ of sonicated herring sperm DNA was used per reaction. The DNA fragments were electrophoresed in $8 \%$ polyacrylamide- $7 \mathrm{M}$ urea gels. The probe from the human c-fos gene was as described (Prywes and Roeder 1987), except that it was labeled with $\left[\alpha^{-32} \mathrm{P}\right] \mathrm{dGTP}$ and DNA polymerase I large fragment (Klenow; New England Biolabs). G/Asequencing lanes were prepared as described (Maxam and Gilbert 1980).

\section{Gel mobility-shift assay}

For experiments that did not involve modification of SRF, the gel mobility-shift assays were performed as described (Prywes and Roeder 1986). Protein extracts were incubated for $30 \mathrm{~min}$ at room temperature with $1 \mathrm{ng}$ of ${ }^{32} \mathrm{P}$-labeled DNA probe (see below) and $2 \mu \mathrm{g}$ of herring sperm DNA in $20 \mu \mathrm{l}$ of binding buffer [ $10 \mathrm{~mm}$ Tris $\mathrm{HCl} / \mathrm{pH} 7.5], 50 \mathrm{~mm} \mathrm{KCl}, 1 \mathrm{~mm}$ dithiothreitol, $0.05 \%$ NP- $40,5 \%$ glycerol, and about $100 \mathrm{ng}$ of carrier protein, usually bacterial extract]. The reaction mixture was then loaded directly onto a $4 \%$ polyacrylamide gel in $0.25 \times$ TBE (25 mM Trizma base, $25 \mathrm{~mm}$ boric acid, and $1 \mathrm{~mm}$ EDTA) and electrophoresed at 150 volts for $1.5 \mathrm{hr}$ at room temperature. The gel was dried and analyzed by autoradiography.

For experiments involving modification of SRF, bacterial or HeLa cell SRF /typically $1 \mu$ l of a $1: 10$ dilution in BC100/100 $\mu \mathrm{g} / \mathrm{ml}$ bovine serum albumin) were incubated for $30 \mathrm{~min}$ at $37^{\circ} \mathrm{C}$ in $25 \mu \mathrm{l}$ of buffer containing $2.5 \mu \mathrm{g}$ BSA, $1 \mathrm{mM}$ DTT, 40 mM HEPES (pH 8.4), 40\% BC100 (total including protein fractions), $3 \mu \mathrm{l}$ of the $\mathrm{P} 110.85-\mathrm{M} \mathrm{KCl}$ fraction, $3 \mathrm{mM} \mathrm{MgCl}_{2}$ and 400 $\mu \mathrm{M}$ ATP (unless otherwise indicated). For the gel mobility-shift assay comparing CKII to the Mono Q kinase fraction, $1 \mu \mathrm{l}$ of heat-treated $\left(70^{\circ} \mathrm{C}, 5 \mathrm{~min}\right) \mathrm{P} 11$ column flowthrough (devoid of the kinase activity/ was included in the incubation reaction to stabilize SRF activity nonspecifically. In this experiment, $2 \mu 1$ of the Mono Q fraction compared with $0.02 \mu \mathrm{l}$ of the CKII preparation $[0.3 \mathrm{mg} / \mathrm{ml}$, purified from bovine testes (Takio et al. 1987) and kindly provided by E. Krebs] was used as the source of kinase. Ten microliters of the modification reactions was added to gel mobility-shift assay buffer (described above) for a final volume of $20 \mu \mathrm{l}$, incubated for $30 \mathrm{~min}$ at room temperature, and run on a $4 \%$ polyacrylamide gel as above. For the phosphatase experiments, $1.5 \mu \mathrm{g}$ of potato acid phosphatase (BoehringerMannheim) with or without $12 \mathrm{~mm}$ sodium phosphate (pH 7.4) was added directly to the modification reaction. The subsequent steps were carried out as described above.

The oligonucleotide used in the gel mobility-shift assays, XGL (Prywes et al. 1988b), is essentially the same as ActL (Treisman 1987). XGL is bound by SRF with high affinity, 10fold better than the c-fos SRE. The nonspecific oligonucleotide competitor, XGLM, contains two point mutations of XGL and has the double-stranded sequence CAATCCCTCCCCCCTTATGAAAGATGCCGATATATCGGCATCTTCTGCAGCA where the underlined nucleotides are changes from $C$ and $G$, respectively, in oligonucleotide XGL.

\section{Antisera}

Peptide C, corresponding to the carboxyl terminus of SRF (CQVNLDTAHSTKSQ) with the amino-terminal cysteine added for coupling purposes, was coupled to ovalbumin and injected into rabbits as described (Prywes et al. 1988b). The resulting sera (anti-SRFC) were affinity purified by passage on a peptide C-thiopropyl Sepharose 6B (Pharmacia) affinity column and eluted with $0.1 \mathrm{M}$ glycine $(\mathrm{pH} 2.5)$ as described by the manufacturer. Peptide $M$, corresponding to SRF amino acids $218-232$, was used as a nonspecific peptide.

\section{Phosphorylation and immunoprecipitations}

BSRF and casein were phosphorylated essentially as described above (see Gel mobility-shift assay) except that $100 \mu \mathrm{Ci}$ of $\left[\gamma^{32}\right.$ P]ATP (6000 Ci/mmol; New England Nuclear) and $20 \mu \mathrm{M}$ nonradioactive ATP were used. Subsequent steps were carried out for all experiments involving phosphorylation of BSRF with $\left[\gamma^{-32} \mathrm{P}\right]$ ATP except the experiments whereby SRF proteins or casein were phosphorylated by CKII and the Mono Q fraction. After phosphorylation for $30 \mathrm{~min}$ at $37^{\circ} \mathrm{C}, \mathrm{NP} 40$ lysis buffer $[0.5$

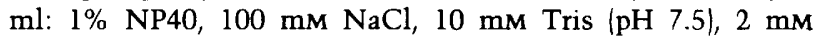
EDTA, $0.5 \mathrm{~mm}$ DTT, and $0.5 \mathrm{~mm}$ PMSF] was added to the reaction, incubated $10 \mathrm{~min}$ on ice, and the lysis mixture was centrifuged at $13,000 \mathrm{rpm}$ for $10-15 \mathrm{~min}$ at $4^{\circ} \mathrm{C}$. Protein A-agarose $(50 \mu l$ of a $50 \%$ solution in NP40 lysis buffer; Bio-Rad) and $3 \mu l$ of preimmune rabbit serum was added to the supernatant. The mixture was rotated at $4^{\circ} \mathrm{C}$ for at least $1 \mathrm{hr}$ and centrifuged for $\mathrm{l}$ min to remove the protein-A agarose. Affinity-purified antibody, anti-SRFC $(10 \mu l)$, was added to the supernatant, and the mixture was incubated at $4^{\circ} \mathrm{C}$ overnight. Some incubations contained $3 \mu \mathrm{g}$ nonspecific peptide $\mathrm{M}$ or $3 \mu \mathrm{g}$ specific peptide $\mathrm{C}$ (against which the serum was generated). Protein A-agarose $(50 \mu$ l) was again added, and the mixture was allowed to rotate at $4^{\circ} \mathrm{C}$ for at least $1 \mathrm{hr}$. The protein $\mathrm{A}$-agarose was pelleted as above and washed $4 \times$ : once with NP40 lysis buffer, twice with NP40 lysis buffer containing $1 \mathrm{M} \mathrm{NaCl}$, and once again with NP40 lysis buffer. The pellet was boiled $5 \mathrm{~min}$ in protein gel sample buffer [ $67 \mathrm{mM}$ Tris (pH 6.8), $2 \%$ SDS, $10 \%$ glycerol, 5 mM EDTA, $0.33 \%$-mercaptoethanol, and $0.02 \%$ bromophenol blue| and electrophoresed on a 9\% SDS-polyacrylamide gel. Prestained protein molecular weight markers (Bethesda Research Laboratories) were used. The gel was soaked in $40 \%$ methanol $/ 10 \%$ acetic acid for $30 \mathrm{~min}$ at room temperature, dried, and analyzed by autoradiography.

For the experiments involving phosphorylation of SRF mutant proteins or casein by CKII and the Mono Q fraction, the kinase reaction was carried out as described above. Where indicated, heparin was included in the incubation reaction. Rather than immunoprecipitation, sample buffer was added directly to the samples, which were boiled and then electrophoresed on $9 \%$ or $12 \%$ SDS-polyacrylamide gels as above. CKII was purified from bovine testes (Takio et al. 1987) and was kindly provided by E. Krebs. The Mono Q kinase fraction was fraction number 23 in Figure 6, C and D. Casein and heparin were purchased from Sigma.

In vivo labeling of $\mathrm{A} 431$ cells was performed as described (Prywes et al. 1988b) with $1 \mathrm{mCi} / \mathrm{ml}$ 32P-inorganic phosphate (ICN) for $3 \mathrm{hr}$ at $37^{\circ} \mathrm{C}$. Cells were washed twice with ice cold TBS [20 mM Tris (pH 7.5) and $150 \mathrm{~mm} \mathrm{NaCl}]$, scraped into $5 \mathrm{ml}$ of TBS, centrifuged at $1000 \mathrm{~g}$ for $5 \mathrm{~min}$, resuspended in $0.5 \mathrm{ml}$ NP40 lysis buffer, and immunoprecipitated as described above. For analysis of phosphotryptic peptides, the labeling was scaled up to include two $15-\mathrm{cm}$ plates and $1.5 \mathrm{mCi} / \mathrm{ml}{ }^{32} \mathrm{P}$-inorganic phosphate in the labeling medium. 
For phosphotryptic peptide analysis, the band corresponding to the phosphorylated protein was cut from the gel and washed with $10 \%$ methanol for $4 \mathrm{hr}$ to remove SDS and dried in a vacuum centrifuge. The gel slices were then digested with $1 \mathrm{ml}$ of a $10 \mu \mathrm{g} / \mathrm{ml}$ solution of sequencing grade trypsin (BoehringerMannheim) in $50 \mathrm{~mm}$ ammonium bicarbonate ( $\mathrm{pH} \mathrm{7.8)} \mathrm{over-}$ night at $37^{\circ} \mathrm{C}$. Trypsin was again added twice and incubated for $8-12 \mathrm{hr}$ each time. The resulting peptides were separated using HPLC and a Vydac C18 reverse-phase column $(4.6 \times 25 \mathrm{~cm})$ with $0.1 \%$ trifluoroacetic acid in water and acetonitrile as buffers $A$ and $B$, respectively. The following gradient was used at $1 \mathrm{ml} / \mathrm{min}: 0-10 \mathrm{~min}$, Buffer $\mathrm{A} ; 10-50 \mathrm{~min}$, linear gradient to $40 \%$ buffer $B$. Fractions of $1 \mathrm{ml}$ were collected and counted in a scintillation counter using scintillation fluid.

Phosphoamino acid analysis of the BSRF HPLC-purified phosphotryptic peptide was performed by two-dimensional thin layer chromatography as previously described (Hunter and Sefton 1980).

\section{Chromatography}

Nuclear extract (40 ml: prepared as in Dignam et al. 1983a) in BC100 was applied to a 20-ml phosphocellulose (Whatman P11) column as described previously (Prywes and Roeder 1987; Dignam et al. 1983b), either with steps of 0.5 and $0.85 \mathrm{M} \mathrm{KCl}$ or with a gradient from $100 \mathrm{~mm}$ to $1 \mathrm{M} \mathrm{KCl}$. The fractions were then assayed for DNA binding enhancement or kinase activity as described above. Two milliliters of a $0.85-\mathrm{M} \mathrm{KCl}$ step fraction, dialyzed to a final concentration of $100 \mathrm{mM} \mathrm{KCl}$ in BC100, was applied to an FPLC Mono Q column (HR 5/5, Pharmacia) and fractions were collected over a gradient of 100 to $500 \mathrm{~mm}$ $\mathrm{KCl}$.

\section{In vitro transcription}

Three fractions were used to provide the basic RNA polymerase II transcription factors (Dignam et al. 1983b): (1) The flowthrough of the P11 column of nuclear extract was passed over a DEAE-cellulose (DE52, Whatman) column and step-eluted with $0.35 \mathrm{M} \mathrm{KCl}$. This step fraction provided TFIIA. (2) The P11 0.5-M KCl step fraction was passed over a doublestranded DNA-Sepharose 4B column (Prywes and Roeder 1987). The flowthrough provided TFIIB, TFIIE, TFIIF, and RNA polymerase. (3) The $\mathrm{P} 110.85-\mathrm{M} \mathrm{KCl}$ step fraction was used to provide TFIID. The in vitro transcription reaction, with the above three fractions ( $3 \mu$ l each), was performed as described previously (Prywes et al. 1988b) except that the Sl nuclease hybridization probe was derived from pFC53 in the same way as described previously for pFC99 (Fisch et al. 1987).

\section{Acknowledgments}

We thank Dr. Richard Treisman for providing us with SRF cDNA clones. We also thank Dr. Edwin Krebs for providing us with purified CKII. This work was supported by grant number CA 50329-01 from the National Cancer Institute, by Basil O'Connor Starter Scholar Research Award No. 5-751 from the March of Dimes Birth Defect Foundation and by support from the Searle Scholars Program/The Chicago Community Trust to R.P.

\section{References}

Ackerman, P. and N. Osheroff, N. 1989. Regulation of casein kinase II activity by epidermal growth factor in human A-431 carcinoma cells. J. Biol. Chem. 264: 11958-11965.
Carroll, D. and D.R. Marshak. 1989. Serum-stimulated cell growth causes oscillations in casein kinase II activity. I. Biol. Chem. 246: 7345-7348.

Cherry, J.R., T.R. Johnson, C. Dollard, J.R. Shuster, and C.L. Denis. 1989. Cyclic AMP-dependent protein kinase phosphorylates and inactivates the yeast transcriptional activator ADR 1. Cell 56: 409-419.

Curran, T. 1988. The oncogene handbook, (ed. E.P. Reddy, A.M. Skalka, and T. Curran), Amsterdam: Elsevier.

Dignam, J.D., R.M. Lebowitz, and R.G. Roeder. 1983a. Accurate transcription initiation by RNA polymerase II in a soluble extract from isolated mammalian nuclei. Nucleic Acids Res. 11: $1475-1489$.

Dignam, J.D., P.L. Martin, B.S. Shastry, and R.G. Roeder. 1983b. Eukaryotic gene transcription with purified components. Methods Enzymol. 101: 582-598.

Edelman, A.M., D.A. Blumenthal, and E.G. Krebs. 1987. Protein serine and threonine kinases. Annu. Rev. Biochem. 56: $563-613$.

Fisch, T.M., R. Prywes, and R. Roeder. 1987. c-fos sequences necessary for basal expression and induction by epidermal growth factor, 12-O-tetradecanoyl phorbol-13-acetate, and the calcium ionophore. Mol. Cell. Biol. 7: 3490-3502.

Gilman, M.Z. 1988. The c-fos serum response element responds to protein kinase C-dependent and independent signals but not to cyclic AMP. Genes Dev. 2: 394-402.

Gilman, M.Z., R.N. Wilson, and R.A. Weinberg. 1986. Multiple protein-binding sites in the $5^{\prime}$-flanking region regulate c-fos expression. Mol. Cell. Biol. 6: 4305-4314.

Gonzalez, G.A. and M.R. Montminy. 1989. Cyclic AMP stimulates somatostatin gene transcription by phosphorylation of CREB at serine 133. Cell 59: 675-680.

Greenberg, M.E., A.L. Hermanowski, and E.B. Ziff. 1986. Effect of protein synthesis inhibitors on growth factor activation of c-fos, c-myc, and actin gene transcription. Mol. Cell. Biol. 6: $1050-1057$

Greenberg, M.E., Z. Siegried, and E.B. Ziff. 1987. Mutation of the c-fos gene dyad symmetry element inhibits serum inducibility of transcription in vivo and the nuclear regulatory factor binding in vitro. Mol. Cell. Biol. 7: 1217-1225.

Hathaway, G.M. and J.A. Traugh. 1979. Cyclic nucleotide-independent protein kinases from rabbit reticulocytes: purification of casein kinases. I. Biol. Chem. 254: 762-768.

Hathaway, G.M., T.S. Lundak, S.M. Tahara, and J.A. Traugh. 1979. Isolation of protein kinases from reticulocytes and phosphorylation of initiation factors. Methods Enzymol. 60: 495511 .

Hathaway, G.M., T.H. Lubben, and J.A. Traugh. 1980. Inhibition of casein kinase II by heparin. I. Biol. Chem. 255: 8038-8041.

Hoey, T., R. Warrior, J. Manak, and M. Levine. 1988. DNAbinding activities of the Drosophila melanogaster evenskipped protein are mediated by its homeo domain and influenced by protein context. Mol. Cell. Biol. 8: 4598-4607.

Hunter, T. and B.M. Sefton. 1980. Transforming gene product of Rous sarcoma virus phosphorylates tyrosine. Proc. Natl. Acad. Sci. 77: 1311-1315.

Jackson, S.P. and R. Tjian. 1988. O-glycosylation of eukaryotic transcription factors: implications for mechanisms of transcriptional regulation. Cell 55: 125-133.

Kishimoto, A., M.S. Brown, C.A. Slaughter, and J.L. Goldstein. 1987. Phosphorylation of serine 833 in cytoplasmic domain of low density lipoprotein receptor by a high molecular weight enzyme resembling casein kinase II. I. Biol. Chem. 262: $1344-1351$.

Klarlund, J.K. and M.P. Czech. 1988. Insulin-like growth factor 
I and insulin rapidly increase casein kinase II activity in BALB/c 3T3 fibroblasts. J. Biol. Chem. 263: 15873-15875.

Krebs, E.G., R.N. Eisenman, E.A. Kuenzel, D.W. Litchfield, F.J. Lozeman, B. Luscher, and J. Sommercorn. 1988. Casein kinase II as a potentially important enzyme concerned with signal transduction. Cold Spring Harbor Symp. Quant. Biol. 53: $77-84$.

Laemmli, U.K. 1970. Cleavage of structural proteins during the assembly of the head of bacteriophage T4. Nature 227: 680685.

Maxam, A. and W. Gilbert. 1980. Sequencing end-labeled DNA. Methods Enzymol. 65: 499-560.

McVey, D., L. Brizuela, I. Mohr, D.R. Marshak, Y. Gluzman, and D. Beach. 1989. Phosphorylation of large tumour antigen by cdc2 stimulates SV40 DNA replication. Nature 341: 503-507.

Norman, C., M. Runswick, R. Pollock, and R. Treisman. 1988. Isolation and properties of cDNA clones encoding SRF, a transcription factor that binds to the c-fos serum response element. Cell 55: 989-1003.

Prywes, R. and R.G. Roeder. 1986. Inducible binding of a factor to the c-fos enhancer. Cell 47: 777-784.

1987. Purification of the $\mathrm{c}$-fos enhancer binding protein. Mol. Cell. Biol. 7: 3482-3489.

Prywes, R., A. Dutta, J.A. Cromlish, and R.G. Roeder. 1988a. Phosphorylation of serum response factor, a factor that binds to the serum response element of the c-fos enhancer. Proc. Natl. Acad. Sci. 85: 7206-7210.

Prywes, R., T.M. Fisch, and R.G. Roeder. 1988b. Transcriptional regulation of c-fos. Cold Spring Harbor Symp. Quant. Biol. 53: 739-748.

Ptashne, M. 1988. How eukaryotic transcriptional activators work. Nature 335: 683-689.

Schroter, H., P.E. Shaw, and A. Nordheim. 1987. Purification of intercalator-released $\mathrm{p} 67$, a polypeptide that interacts specifically with the c-fos serum response element. Nucleic Acids Res. 15: 10145-10158.

Sheng, M., S.T. Dougan, G. McFadden, and M.E. Greenberg. 1988. Calcium and growth factor induced pathways of c-fos transcriptional activation require different upstream regulatory sequences. Mol. Cell. Biol. 8: 2787-2796.

Sommercorn, J., J.A. Mulligan, F.J. Lozeman, and E.G. Krebs. 1987. Activation of casein kinase II in response to insulin and to epidermal growth factor. Proc. Natl. Acad. Sci. 84: $8834-8838$.

Sorger, P.K. and H.R.B. Pelham. 1988. Yeast heat shock factor is an essential DNA-binding protein that exhibits temperature-dependent phosphorylation. Cell 54: 855-864.

Sorger, P.K., M.J. Lewis, and H.R.B. Pelham. 1987. Heat shock factor is regulated differently in yeast and HeLa cells. $\mathrm{Na}$ ture 329: $81-84$.

Studier, F.W. and B.A. Moffatt. 1986. Use of bacteriophage T7 RNA polymerase to direct selective high-level expression of cloned genes. J. Mol. Biol. 189: 113-130.

Takio, K., E.A. Kuenzel, K.A. Walsh, and E.G. Krebs. 1987. Amino acid sequence of the beta subunit of bovine lung casein kinase II. Proc. Natl. Acad. Sci. 84: 4851-4855.

Treisman, R. 1985. Transient accumulation of c-fos RNA following serum stimulation requires a conserved 5 ' element and c-fos 3' sequences. Cell 42: 889-902.

. 1986. Identification of a protein-binding site that mediates transcription response of the c-fos gene to serum factors. Cell 46: 567-574.

1987. Identification and purification of a polypeptide that binds the c-fos serum response element. EMBO $/$. 6: $2711-2717$.
Yamamoto, K.K., G.A. Gonzalez, W.H. Biggs III, and M.R. Montminy. 1988. Phosphorylation-induced binding and transcriptional efficacy of nuclear factor CREB. Nature 334: 494-498. 


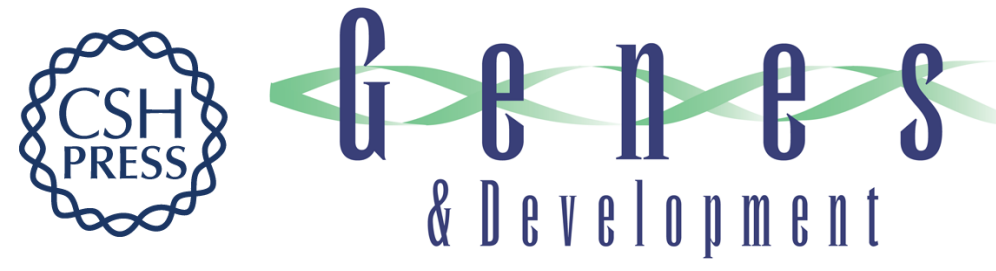

\section{Casein kinase II enhances the DNA binding activity of serum response factor.}

J R Manak, N de Bisschop, R M Kris, et al.

Genes Dev. 1990, 4:

Access the most recent version at doi:10.1101/gad.4.6.955

References This article cites 40 articles, 18 of which can be accessed free at:

http://genesdev.cshlp.org/content/4/6/955.full.html\#ref-list-1

License

Email Alerting

Service

Receive free email alerts when new articles cite this article - sign up in the box at the top right corner of the article or click here.

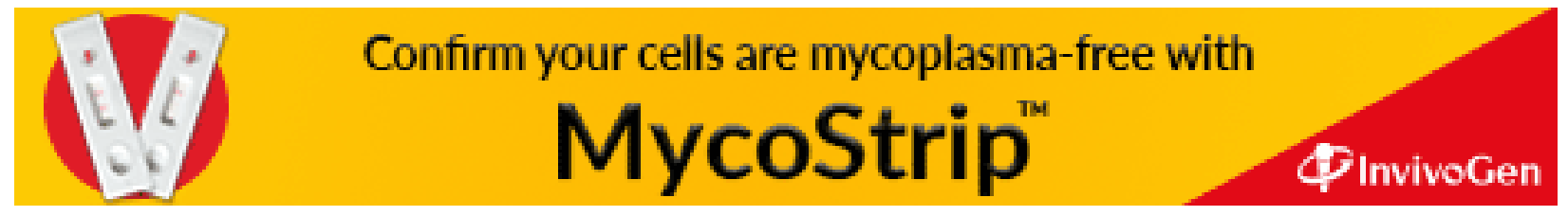

